\section{Til ettertanke om hjernen}

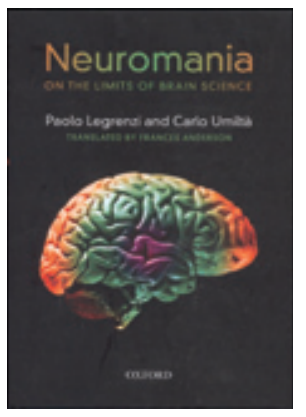

\section{Paolo Legrenzi, Carlo Umiltà \\ Neuromania}

On the limits of brain science. 114 s. Oxford: Oxford University Press, 2011. Pris GBP 15 ISBN 978-0-19-959134-3

Denne boken er en utfordring å anmelde fordi den både er et innlegg $\mathrm{i}$ en komplisert og omfattende debatt om nevrovitenskapens plass i en bredere samfunnsanalyse, og den er en del av en diskusjon om «mind versus brain»-problemet, belyst med moderne bildefremstilling av hjernen. For disse forfatterne synes «mind» flere steder å være åndelig og transcendental, og ikke psykisk eller vidt forstått kognitiv. «Mind» er for øvrig et ord som vi mangler en god norsk oversettelse for, og hvis innhold nevrobiologiske forskere åpenbart heller ikke er enige om.

Boken inneholder mange verdifulle kritiske refleksjoner rundt ukritisk bruk av hjerneskanning i rammen av neologismer som nevroøkonomi, nevroetikk, nevroestetikk etc. Forfatterne siterer og diskuterer undersøkelser som pretenderer å gi en mer vitenskapelig forståelse av politisk overbevisning eller politiske valg knyttet til lokal aktivering eller aktiveringsmønstre i hjernen (s. 88). Korrekt anføres lakonisk at korrelasjon ikke alltid er synonymt med kausalitet, dvs. at konklusjoner om kognitive prosesser trekkes uten at vi engang vet om de «funksjonene» som undersøkes, er lokalisert, delvis aktivert eller fjernstyrt fra områder i hjernen som viser endret blodtilstrømning i en testsituasjon. Hjernen reguleres som kjent av nettverk, og deres interaksjoner er vi per dags dato bare delvis i stand til å analysere.

Boken er ført i pennen av to professorer i psykologi fra Italia. De skriver: "As we have seen in the previous chapter, new techniques which seem to photograph the brain (...) have promoted a revival of the classical utopia of reducing the mind to the function of the brain» (s. 48-9). Vel, det er riktig at man overfokuserer på hvor i nye hjernestudier med funksjonell MR og at hva og hvordan ofte kan komme til kort, men at funksjoner i hjernen er en forutsetning for funksjoner $\mathrm{i}$ «the mind» burde ikke være kontroversielt. Forfatterne bringer altså egen ballast inn i diskusjonen. Her dukker ånd versus legeme-diskusjonen opp i nevrovitenskapelig kappe! Alternativt er dette rettet mot en reduksjonistisk tenkning om at «the mind» kan reduseres til fysiologiske hjerneprosesser som man kan forklare. I mine øyne har forfatterne også flere uheldige vurderinger og utsagn som skjemmer budskapet, f.eks. hevder de at "the development of the thinking of Sigmund Freud provides an excellent example of the transition from the modular to the holistic concept» (s. 7). Ettersom Freud aldri tok noe seriøst utgangspunkt i nevrofysiologisk kunnskap, blir utsagnet lite meningsfylt.

Kapitlene har titler og temaer som Before neuroimages, From blood flow to mental functions, Cognitive subtractions, Mirror Neurons, Cognitive processes: what they are, how they work and where they are located samt Neuroeconomy, Neuromarketing, Neurodesign, Neuroesthetics, Neuroethics og Neurotheology. En riktig påstand er at informasjon om antatt cerebral lokalisasjon av et fenomen på magisk vis har en tendens til å gjøre dårlige eller sviktende forklaringer tilfredsstillende i bl.a. populærvitenskapelig og mediemessig sammenheng.

Denne lille boken spenner over for mange temaer. Kunst, aspekter av kreativitet, estetikk, politikk, nevronalt korrelat til emosjoner og valg relevant for markedsføring, etikk, religiøs tro etc. gjør at dette ikke blir et godt grunnlag for konklusjoner om temaer som inklu- derer kriterier for liv og død. Ganske så luftige blir kommentarene, f.eks. på s. 93-5, når forfatterne snakker om kriterier for liv og død, samfunnsforhold og sammenhengen mellom «brain and mind» og «the body» (legemet) som motvekt til «the mind».

Som en ettertankens refleksjon om forsiktighet i tolking av moderne hjerneskanning og populistisk nevrovitenskap i sin helhet, har boken en funksjon. Den er egentlig best egnet for lekfolk med en for stor tiltro til hjerneskanningens fortreffelighet og at slik bildefremstilling av hjernen gir enkle svar på komplekse sammenhenger. Alt i alt er dette kanskje en bok til ettertanke for alle.

Bernt A Engelsen

Epilepsienheten

Nevrologisk avdeling

Haukeland universitetssykehus

\section{Grunnleggende om hematologi}

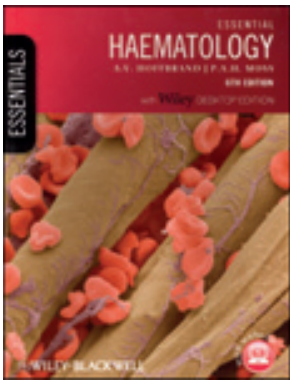

Victor Hoffbrand, Paul Moss

Essential haematology

6. utg. 454 s, tab, ill. Chichester

Wiley-Blackwell, 2011. Pris GBP 40

ISBN 978-1-4051-9890-5

Hematologi er et frontfag i medisinen, og i dette faget har man vært blant de første til å anvende ny og avansert metodikk for diagnostikk og behandling. Spesielt gjelder dette bruk av celle- og molekylærbiologiske teknikker i diagnostikk av sykdom og bruk av stamceller og genterapi ved behandling. Den forste utgaven av Essential haematology kom i 1980 på et tidspunkt da det meste av dette ennå var tidlig basalforskning. Denne sjetteutgaven er en oppdatert versjon som på en forbilledlig måte integrerer tekst, bilder og bruk av Internett.

Det er 30 kapitler som dekker alle grunnleggende deler av hematologien, inklusive anemier og hemoglobinsykdommer, benigne sykdommer knyttet til hvite blodceller, maligne blodsykdommer (leukemi, lymfom og myelomatose), stamcelletransplantasjon, trombose og hemostaseproblemer. Boken er tilnærmet oppdatert med nye data per 2010. Hvert kapittel inneholder en basistekst rettet mot medisinstudenter. I tillegg er det en utfyllende tekst for spesielt interesserte og spesialistkandidater som er merket med en strek i margen. Tabeller og bilder er generelt meget illustrative. Hvert kapittel har en oppsummering over 0,5-1 side.

I tillegg til papirversjonen er det også en Internett-basert modul knyttet til en unik kode for hver enkelt bok. Denne tilgangen gjør det mulig å laste den ned elektronisk, laste ned tabellene og å laste ned figurene i powerpointformat. I det elektroniske formatet er det tilgang til egentesting på nettet i form av en serie spørsmål med fire svarmuligheter. Det er stort sett gode og relevante spørsmål som gjør det mulig å teste egen kunnskap og forståelse av stoffet.

Generelt er boken inspirerende og lett å lese. Noen vil kanskje mene at en svakhet er mangel på kliniske eksempler. Etter mitt skjønn er dette likevel en svært vellykket lærebok i et til dels vanskelig fag. Jeg kan anbefale den til studenter, men også spesielt til spesialistkandidater.

\section{Per Morten Sandset}

Avdeling for blodsykdommer

Oslo universitetssykehus, Rikshospitalet 